\title{
Review
}

\section{Role of Glycosylation in Vascular Calcification}

\author{
Ainun Nizar Masbuchin ${ }^{1,2}$, Mohammad Saifur Rohman ${ }^{2}(\mathbb{D}$ and Ping-Yen Liu $1,3, *$ (]) \\ 1 Institute of Clinical Medicine, College of Medicine, National Cheng Kung University, Tainan 70457, Taiwan; \\ nizar.fkub08@gmail.com \\ 2 Department of Cardiology and Vascular Medicine, Faculty of Medicine, Universitas Brawijaya, \\ Malang 65111, Indonesia; ippoenk@ub.ac.id \\ 3 Division of Cardiology, Internal Medicine, National Cheng Kung University Hospital, College of Medicine, \\ National Cheng Kung University, Tainan 70403, Taiwan \\ * Correspondence: larry@mail.ncku.edu.tw; Tel.: +886-6-235-3535 (ext. 4602); Fax: +886-6-275-3834
}

\section{check for}

updates

Citation: Masbuchin, A.N.; Rohman, M.S.; Liu, P.-Y. Role of Glycosylation in Vascular Calcification. Int. J. Mol. Sci. 2021, 22, 9829. https://doi.org/ $10.3390 /$ ijms22189829

Academic Editor: Jane A. Leopold

Received: 24 August 2021

Accepted: 8 September 2021

Published: 11 September 2021

Publisher's Note: MDPI stays neutral with regard to jurisdictional claims in published maps and institutional affiliations.

Copyright: (C) 2021 by the authors Licensee MDPI, Basel, Switzerland. This article is an open access article distributed under the terms and conditions of the Creative Commons Attribution (CC BY) license (https:/ / creativecommons.org/licenses/by/ $4.0 /)$.

\begin{abstract}
Glycosylation is an important step in post-translational protein modification. Altered glycosylation results in an abnormality that causes diseases such as malignancy and cardiovascular diseases. Recent emerging evidence highlights the importance of glycosylation in vascular calcification. Two major types of glycosylation, N-glycosylation and O-glycosylation, are involved in vascular calcification. Other glycosylation mechanisms, which polymerize the glycosaminoglycan (GAG) chain onto protein, resulting in proteoglycan (PG), also have an impact on vascular calcification. This paper discusses the role of glycosylation in vascular calcification.
\end{abstract}

Keywords: vascular calcification; medial calcification; O-glycosylation; N-glycosylation; proteoglycan

\section{Introduction}

Vascular calcification (VC) is an independent predictor of mortality and morbidity in cardiovascular disease [1]. Coronary artery plaque calcification increases mortality 1.7-fold, whereas an extensive form increases it 60-fold [2]. It also increases economic burden in the form of cardiovascular disease [3]. Vascular calcification is an active process of depositing calcium in the form of hydroxyapatite in the vascular matrix [4].

Currently, vascular calcification is considered to resemble bone ossification and it has pro- and anti-calcification factors. An imbalance of these factors in certain diseases such as atherosclerosis, chronic kidney disease (CKD), and diabetes lead to vascular calcification formation [5]. These factors are regular proteins that need canonical post-translational modification (PTM) processing, and the most common PTM is glycosylation. Some of these factors will undergo glycosylation to become fully functional. Accumulating evidence highlights the importance of glycosylation in vascular calcification. In this review, we summarize and discuss the latest evidence of glycosylation in vascular calcification.

\section{Classification, Clinical Consequences, and Risk Factors of Vascular Calcification}

Vascular calcification is an ectopic mineralization and can be classified into two forms depending on where the mineral is deposited [6,7]. The first type is intimal calcification, which is commonly observed in atherosclerosis, hyperlipidemia, and metabolic syndrome [8]. It is a patchy and discontinuous process involving macrophage and vascular smooth muscle cells (VSMC) in the lipid-rich region of atherosclerotic plaques [9]. The second type of VC is medial calcification, which is commonly observed in CKD, diabetes mellitus, aortic aneurysm, and aging patients. This type of VC (called Monckeberg's sclerosis) is described as sheet-like calcification in the medial layer with concentric thickening of the vessel wall $[9,10]$, and it is less directly correlated with inflammation $[4,11]$.

Both of the calcification types have their own clinical consequences. The clinical complications of intimal calcification are plaque rupture, myocardial infarction, and stroke. Medial calcification increases arterial stiffness, arterial pulse pressure, increased pulse wave 
velocity, and all-cause mortality [8]. Both of the VC types share common and specialized mechanisms. Common mechanisms include oxidative stress, apoptosis, mitochondrial dysfunction, mechanical stress, and cell death. Loss of inhibitors and VSMC senescence are special drivers of medial calcification, whereas the inflammation process is found in intimal calcification [8]. The risk factors for developing intimal calcification are advanced age, diabetes mellitus, dyslipidemia, hypertension, being male, smoking, and hyperphosphatemia. Advanced age, diabetes mellitus, renal dysfunction (decrease in glomerulus filtration rates), hypercalcemia, hyperphosphatemia, and dialysis duration are risk factors for developing medial calcification [12].

\section{Mechanism of Vascular Calcification}

Bone is largely composed of hydroxyapatite and hydroxyapatite crystal grown from an extruded matrix vesicle (MV). Matrix vesicle buds from osteoblasts. It serves as the nidus for calcium-phosphate deposition within the vascular wall $[13,14]$. Vascular smooth muscle cell can similarly exude MVs as a mechanism to promote VC [4]. Matrix vesicle contains enzymes and factors including alkaline phosphatase. They concentrate calcium and initiate hydroxyapatite mineral crystallization. The matrix vesicle in the vasculature is analogue to the MV of skeletal tissue. VSMC, like osteoblasts, can also produce nucleating vesicles as a result of primary osteogenic differentiation [15].

Vascular calcification is considered an active process. Four different VC factors have long been proposed. They are: (1) loss of inhibition, (2) induction of bone formation, (3) circulating nucleation complexes, and (4) cell death [16]. A passive process is involved in this process via a thermodynamic mechanism, which is elevated calcium and phosphateinduced apatite nucleation and crystal growth. The induction of bone formation results from the differentiation of pericytes and/or VSMCs. Circulating a nucleating complex or locally released MV serves as a site for calcium crystallization. Dead cells also serve as nucleating sites for calcium crystals [11].

Physiologically, VC is inhibited by the balance of inhibitors and inducers. The inhibitors are required to prevent vascular calcification in basal conditions. At present, VC inhibitors are identified. They are inorganic pyrophosphatase (PPi), matrix Gla protein (MGP), osteopontin (OPN), osteoprotegerin (OPG), fetuin-A, and klotho [17]. The calcification inducers include phosphate, bone morphogenic protein 2 (BMP2), alkaline phosphatase (ALP), and fibroblast growth factor 23 (FGF23) [5].

Vascular calcification is initiated by MVs released by apoptotic cells and proliferativephenotype VSMCs [11]. These MVs are deposited in the vessel wall and serve as a nucleation site for calcification $[13,18]$. Such vesicles contain proteins related to calcification and enzymes that are responsible for extracellular matrix cross-linking [13]. Under highphosphate conditions, VSMC uptakes phosphate via a phosphate transporter, Pit-1. VSMC will eventually undergo differentiation to osteoblast-like cells and subsequently downregulate calcification inhibitors [7].

\section{Regulatory Factors in Vascular Calcification}

\subsection{Calcification Inhibitors}

Normally, healthy contractile-phenotype VSMC secretes MV containing MGP and Fetuin-A to inhibit calcification [14]. MGP is a well-established inhibitor of vascular calcification. MGP can inhibit BMP as well as calcium mineral itself. MGP requires posttranslational modification to be active and needs vitamin $\mathrm{K}$ dependent carboxylation. Epidemiological studies support the role of vitamin $\mathrm{K}$ in vascular calcification. Warfarin, which is capable of inhibiting vitamin K, can inhibit MGP carboxylation. Therefore, vitamin K deficiency supports vascular calcification [15].

Fetuin-A, a protein secreted by hepatocyte into circulation, is capable of inhibiting ectopic calcification in a CKD model $[19,20]$. Fetuin A exerts its inhibitory activity by forming colloid with minerals called calciprotein particles (CPP) [21]. It only inhibits de novo calcium phosphate formation [22]. Fetuin-A is endocytosed by VSMC in the presence 
of high calcium [23] and it reduces the ability of MV secreted by endocytosing VSMC to calcify [18]. It seems that the ability of fetuin-A in decreasing VC is concentration-driven. Low levels of fetuin-A decrease VC, whereas high levels increase inflammation, thereby increasing cardiovascular events. Recent studies revealed that a higher level of fetuin-A increases risk of cardiovascular mortality in patients with moderate calcium scores and exacerbates the progression of cardiac dysfunction [24,25].

The receptor activator of nuclear factor- $\mathrm{KB}$ ligand (RANKL), which is a factor for regulating osteoclastic activity, can induce VC via the osteogenic differentiation factor RUNX2. Oxidized lipids and oxidants can increase RANKL in VSMC. RANKL has a soluble receptor called OPG. OPG treatment reduces vascular calcification. The effects of OPG treatment may occur via downstream pathways, MSX2, and ALP [15]. BMP2 plays an important role in vascular calcification in atherosclerotic plaques, $\mathrm{CKD}$, and diabetes mellitus $[10,26]$.

Inorganic pyrophosphatase (PPi) can strongly inhibit hydroxyapatite formation in VC [5]. PPi is circulated and locally secreted by VSMCs. Bellosta et al. [27] demonstrated that PPi secreted by VSMC is important in decreasing vascular calcification.

Recently, autophagy became more of a concern regarding VC. Autophagy is the mechanism of internal cellular components' digestion that recycles nutrients and energy. It is involved in survival, differentiation, and functioning bone cells [28]. Evidence has shown that autophagy decreases VC $[29,30]$.

\subsection{Calcification Inducer}

Phosphate can induce mineralization physico-chemically. It also regulates and coordinates cell signaling through a specialized transportation that promotes calcification. The Pit-1 is a channel that is responsible for phosphate co-transport into VSMC. The increasing cellular phosphate level signals osteogenic gene expression and suppresses VSMC genes. $\beta$-glycerophosphate is a well-known inducer of VSMC calcification and is commonly used for studying VSMC calcification in vitro. The Pit-1 is subject for regulation by calcium, BMP2, and platelet-derived growth factors (PDGF). Increasing these factors can upregulate Pit-1 [5].

BMP2, BMP4, and BMP6 increase plaque formation via pro-inflammatory and pro atherogenic effects and promote differentiation. BMP2 increases RUNX2, the master transcriptional regulator to promote mineralization, in VSMC. BMP2 and BMP4 are also associated with VC in CKD. High phosphate (which is commonly observed in CKD) and BMP2 induce mineralization in addition to RUNX2 and MSX2 expression in a $\beta$-catenindependent manner. BMP2-MSX2 signaling promotes calcification in diabetic vascular disease by inducing myofibroblast to osteoblast-like cells [22]. BMP2 also regulates Pit-1, which is a phosphate transporter. The increasing BMP leads to an increase in Pit- 1 and subsequently leads phosphate transport into cells, thereby promoting VC [5].

Transforming Growth Factor $\beta$ (TGF $\beta$ ) is a member of the TGF $\beta$ family, which belongs to the TGF $\beta$ superfamily. The BMP family also belongs to the TGF $\beta$ superfamily [31]. In general, the binding of TGF $\beta$ to its receptor activates smad $2 / 3$ as downstream signaling, whereas BMP ligand binding to its receptor leads to smad $1 / 5 / 8$ signaling [31]. TGF $\beta$ can also exert its effects through a non-smad pathway (through the Mitogen Activated Protein Kinase (MAPK) pathway). TGF $\beta-1$ is known to have the ability to induce VSMC calcification by stimulating it to differentiate into osteoblast-like cells [32]. It is also highly expressed in calcified aortic valve tissue [33]. However, Shimokado et al. reported the paradox that TGF $\beta$ decreases VSMC calcification [34]. This result can be explained as follows: activation smad $2 / 3$ by TGF $\beta$ inhibits RUNX 2 expression, leading to a decrease in calcification, whereas the activation of non-smad pathways by TGF $\beta$ yields the opposite effect. In contrast to TGF $\beta$, smad $1 / 5 / 8$ activation by BMP2 increases RUNX2 levels and activity, leading to calcification [35]. Therefore, the effect of TGF $\beta$ in VC is likely dependent on the activated downstream pathway. Activating a non-smad pathway (MAPK pathway) could lead to RUNX2 activation and subsequently induce VC [35]. Furthermore, TGF $\beta$ 
is involved in the induction of MGP, which acts as a vascular calcification inhibitor [36]. Finally, evidence showed complex cross-talk between TGF $\beta$, BMP, and other pathways [35], which has implications for decreasing VC [37].

The alkaline phosphatase is an enzyme that breaks down the mineralization inhibitor pyrophosphatase. Additional novel phosphatase is found in a matrix vesicle called phosphatase, orphan 1 (PHOSPHO1). Inhibition of PHOSPHO1 in VSMC also inhibits matrix calcification in vitro [15]. Recent evidence reported that glycosylation differences contribute to catalytic properties among bone alkaline phosphatases [38].

FGF23 is the most potent phosphate regulator. FGF23 is synthesized by osteocytes and secreted into circulation. It exerts its effects after binding to a receptor, klotho, in the kidneys. This binding allows the regulation of phosphate absorption [39]. FGF23 is reported to be expressed in human calcified vascular tissue [40].

Cellular components are also involved in the calcification process. The VSMC has long been identified as a cell that is capable of differentiating into osteoblast-like cells through various mechanisms [41,42]. Resident pericytes have the ability to transdifferentiate into bone-forming cells as well $[17,43,44]$. Bone-marrow-derived cells also contribute to chondrocyte-like cells in intimal calcification [45].

\section{Glycosylation}

Glycosylation is the post-translational process of the enzymatic addition of a saccharide compound to another saccharide, protein, or lipid [46,47]. Protein glycosylation pathways take place in the secretory pathways (endoplasmic reticulum (ER) and golgi), cytoplasm, nucleus, and mitochondria [48]. Glycosylation marks protein for further processing, e.g., tags protein for insertion into the cell membrane or secretion from the cell. It also modifies intracellular proteins [49]. Glycosylation helps protein to fold properly and can inhibit protein degradation by protecting it from proteases [50-52]. Glycosylation is involved in a wide variety of biological processes, such as receptor interaction, in addition to protein secretion and transport. A protein can have multiple glycosylation sites [53]. Glycosylation is a multiple-step process involving many enzymes. The stages of glycosylation consist of initiation, core extension, branch elongation, and capping [48]. There are 16 distinct glycosylation pathways, which are distinguished by sugar-protein linkage, initial monosaccharides linked to protein, and unique initiating enzymes [48], including $\mathrm{N}$-glycosylation, O-glycosylation, C-manosylation, phosphoglycosylation, and glypiation [54].

N-linked glycosylation and O-linked glycosylation are the major types of glycosylation found in mammalian cells [55-57]. N-linked glycosylation is the attachment of glucose to an arginine residue. N-linked glycosylation takes place in ER and golgi [58]. The initiation process of this glycosylation takes place in ER co-translationally or post-translationally, which involves the oligosaccharyltransferase complex (OST) [48]. O-glycosylation is the addition of a glucose compound to the Thr/Ser residue of a target protein. Eighty percent of secreted proteins that traffic secretory pathways are O-glycosylated [57]. In contrast to N-linked glycosylation, O-linked glycosylation takes place post-translationally only in golgi $[59,60]$. Enzymes involved in this glycosylation are involved in the initiation process. Initiation of O-linked glycosylation is catalyzed by the GALNTs family and it has functional redundancy [61]. Some complex glycans (e.g., proteoglycans) are composed of either $\mathrm{N}$-linked or O-linked glycosylation through a process of initiation and elongation [62] The initiation step is the formation of a tetrasaccharide linker, catalyzed by different enzymes: the UDP-xyl transferase, UDP-Gal transferase I, UDP-Gal transferase II, UDPGlc transferase I, and UDP-Gal transferase, respectively [62]. The fifth saccharide in the linker will determine the fate of the glycosaminoglycan (GAG): whether it will become a chondroitin/dermatan sulfate GAG or heparan sulfate/heparin GAG. Elongation of a linear chain is catalyzed by different enzymes depending on the fate of the GAG. In chondroitin sulfate, for example, the elongation of the linear repeating disaccharide region is catalyzed by a chondroitin polymerase complex, which consists of many enzymes [63]. 
Common GAG found in human tissues include chondroitin sulfate, dermatan sulfate, heparan sulfate, and heparin [62].

Glycosylation is involved in many diseases [64]. It has been the main research focus regarding cancer for decades $[46,65]$. It is also thought to contribute to the development of diabetic nephropathy by interfering with kidney tubular cells' ion transport, leading to necrotic cell death [66]. Glycosylation is also involved in cardiovascular diseases [67]. The recent genome-wide association study (GWAS) revealed a correlation between glycosylation and lipid metabolism, including HDL and triglyceride, which has been extensively studied $[68,69]$. Glycosylation is also involved in the development of atherosclerosis disease [70]. GWAS revealed that the gene responsible for glycosylation is associated with coronary in-stent restenosis (ISR) [71]. Adhikara et al. [72] highlight the importance of GAG synthesis in the development of atherosclerosis. Finally, accumulating evidence supports the role of glycosylation in calcification and bone metabolism [73,74] as well as chondrogenic differentiation [75]. Recent studies also reported on the role of glycosylation in VC [76]. The glycosylation of VC regulatory factors leads to various effects on VC (Table 1).

Table 1. Glycosylation of proteins related to vascular calcification.

\begin{tabular}{|c|c|c|c|c|}
\hline Enzyme & Glycosylation Type & $\begin{array}{l}\text { Glycosylated } \\
\text { Protein }\end{array}$ & Effect on VC & Reference \\
\hline $\mathrm{N} / \mathrm{A}$ & N-glycosylation & IGFR1 & Decrease & [76] \\
\hline $\mathrm{N} / \mathrm{A}$ & N-glycosylation & $\mathrm{BMP} 2, \mathrm{BMP} 2 \mathrm{R}$ & Increase & [77] \\
\hline $\mathrm{N} / \mathrm{A}$ & N-glycosylation & Fetuin-A & Decrease & \\
\hline $\mathrm{N} / \mathrm{A}$ & N-glycosylation & TGFßR & Increase & [78] \\
\hline OGT & $\begin{array}{l}\text { O-glycosylation } \\
\text { (GlcNac) }\end{array}$ & AKT & Increase & [79] \\
\hline OGT & $\begin{array}{l}\text { O-glicosylation } \\
\text { (GlcNac) }\end{array}$ & YAP & Increase & [80] \\
\hline GALNT3 & $\begin{array}{l}\text { O-glycosylation } \\
\text { (GalNac) }\end{array}$ & FGF23 & Increase & [81] \\
\hline OGT, OGA & O-glycosylation & Runx2 & Increase & {$[82,83]$} \\
\hline EXT1, EXTL2 & Mixed & Proteoglycan & Various & [84-87] \\
\hline $\begin{array}{l}\text { Abbreviations: OG } \\
\text { Acetylgalactosamin } \\
\text { ferase 2; IGFR1: In } \\
\text { Morphogenic Prote } \\
\text { FGF23: Fibroblast G }\end{array}$ & $\begin{array}{l}\text { N-acetylglucosaminyltr } \\
\text { insferase 3; EXT1: Exos } \\
\text { e-like Growth Factor R } \\
\text { ceptor; TGF } \beta \text { R: Transfo } \\
\text { th Factor 23. GlcNac; N- }\end{array}$ & $\begin{array}{l}\text { erase; OGA: } \beta-\mathrm{Na} \\
\text { Glycosyltransferc } \\
\text { tor 1; BMP2: Bone } \\
\text { ig Growth Factor } \\
\text { ylglucosamine; Ga }\end{array}$ & $\begin{array}{l}\text { Flucosaminidas } \\
\text { EXTL: exostosi } \\
\text { phogenic Prote } \\
\text { ptor; YAP: Yes- } \\
\text { N-Acetylgalact }\end{array}$ & $\begin{array}{l}\text { ALNT3: pp- } \\
\text { ke glycosyltri } \\
\text {; BMP2R: Bo } \\
\text { ociated Prote } \\
\text { mine. }\end{array}$ \\
\hline
\end{tabular}

Besides the enzymatic glycosylation explained above, there is also non-enzymatic glycosylation, which does not require enzymes. It is a reaction that leads to the formation of an advanced glycation end product (AGE), which is a commonly-observed non-enzymatic glycosylation product in diabetic patients [48]. This review focuses on enzymatic glycosylation.

\section{N-glycosylation and Vascular Calcification}

$\mathrm{N}$-glycosylation is the most widely studied glycosylation. The work of Siddals et al. [76] was the first study to link N-glycosylation with VC. As many epidemiological studies found a correlation between statin and VC, Siddals et al. used statin to deplete the substrate required for $\mathrm{N}$-glycosylation and also used tunicamycin as a specific Nglycosylation inhibitor. In the presence of $\beta$-Glycerophosphate as a calcification inducer, they found that statin and N-glycosylation inhibitors attenuate inhibitory effects of IGF in VC. They also found that $\mathrm{N}$-glycosylation inhibitors decrease IGFR surface expression and its downstream signaling.

BMP2 is a well-known signaling molecule involved in VC [10,26]. It promotes phosphate uptake, phenotypic modulation, and the calcification of human VSMCs [88]. It has been reported that BMP has N-glycosylation and O-glycosylation sites [89]. Hang 
et al. [77] reported that N-glycosylation is required for BMP2 secretion and osteoblast differentiation. Mutation of an N-glycosylation site at N135Q impairs BMP-2 secretion. Overexpressing the mutant causes accumulation and induces ER stress. N-glycosylation is required for the proper folding of BMP2 proteins. The mutation also reduces BMP2's ability to induce osteoblast differentiation. Furthermore, van de Watering et al. reported that non-glycosylated BMP2 has reduced biological activity compared to glycosylated BMP2. However, their study found that non-glycosylated BMP2 retains its ability to induce osteoblastic differentiation [90]. Other groups worked on BMP2 receptors and found that $\mathrm{N}$-glycosylation of BMP2 receptors enhance the binding to its ligand, BMP2 [91]. It is known that the BMP2 receptor type 2 bears an $\mathrm{N}$-glycosylation site in the extracellular domain [92]. Despite this evidence, there are currently no reports of a direct correlation between BMP2 glycosylation and vascular calcification. The role of BMP2 and its receptor in inducing VC, however, is well known. Therefore, it is tempting to hypothesize that modifying the glycosylation on this receptor could possibly affect VC.

TGF $\beta$ has been identified as a cause of vascular calcification by promoting VSMC differentiation to osteoblast-like cells [32,93]. TGF $\beta$ is subjected to N-glycosylation [94]. Treatment with tunicamycin (an inhibitor of $\mathrm{N}$-glycosylation) blocks TGF $\beta$ secretion from the cell, and therefore leads to intracellular accumulation. Moreover, its receptor, TGF $\beta R$, is also subjected to $\mathrm{N}$-acetylglucosamine (GlcNAc) regulation. TGF $\beta \mathrm{R}$ is glycosylated in the extracellular domain, which is the binding domain. Removal of glycosylation impairs interaction with its ligand and fails to elicit downstream signaling [95]. Indeed, blocking glycosylation affects vascular calcification. Wen et al. [78] demonstrated that blocking fucosylation, the specialized form of $\mathrm{N}$-glycosylation, decreases vascular calcification. The absence of fucose core in TGF $\beta$ R markedly dysregulates downstream TGF $\beta / \operatorname{smad} 2 / 3$ signaling.

Fetuin-A harbors two N-glycosylation and two O-glycosylation sites in the A chain and two O-glycosylation sites in the B chain [96]. Fetuin-A is well-known as anti-vascular calcification [22]. Evidence has shown that phosphorylated fetuin-A is associated with aortic stiffness and renders pro-calcification milieu [97]. A genetic study revealed the association of polymorphism of the fetuin gene (ASHG) and calcium serum [98], and, surprisingly, the risk of VC [99]. Furthermore, mutation analysis by another group found that $A H S G$ gene mutation causes a change in glycosylation. This mutation changes $\mathrm{Thr}$ to Ser at position 256 and eventually decreases fetuin-A O-glycosylation. The same study also revealed the increase in fucosylation on the N-glycosylation site Asn-176 in sepsis patients [100]. Although there have been no studies that directly correlate fetuin-A glycosylation and VC, the results from the genetic association studies and glycoproteomic studies seem convincing and, therefore, need to be further elaborated.

Galectin-3 is a member of the $\beta$-galactoside-binding lectin family, which interacts with $\beta$-galactoside on glycoconjugate expressed on cell surface receptors and cellular matrix proteins. It has been implicated in the control of cell differentiation, growth, adhesion, migration, and apoptosis [101,102]. It is expressed in various tissues, resides in the cytoplasm or nucleus, and is also secreted out from the cell [103]. Epidemiological studies showed a correlation between galectin-3 and aortic calcification [104]. Recently, galectin-3 is involved in vascular osteogenesis by inducing VSMC differentiation into osteoblast-like cells (reviewed in [103]). Interestingly, the work of Nielsen et al. revealed that galectin-3 has strong binding with glycoconjugate containing N-glycan. Perturbing glycoconjugates' synthesis by interfering with various glycotransferases (enzymes that responsible for glycosylation process) decreases galectin-3 and glycoconjugates' binding [101]. Finally, Ibarrola et al. demonstrated the beneficial effect of galectin-3 blockade in VC [105].

\section{O-glycosylation and Vascular Calcification}

Although O-glycosylation is a common glycosylation type, there are fewer studies that investigate it compared to $\mathrm{N}$-glycosylation. O-GlcNAcylation is the process of the attachment of O-GlcNac to a target protein catalyzed by $\beta$-N-acetylglucosaminyltransferase 
(OGT) [80]. Heath et al. [79] was the first to report the importance of O-glycosylation (O-GlcNAcylation) and VC in a diabetes mellitus setting. Streptosozin-induced calcification mice showed an increase of aortic O-GlcNAcylation. Treatment with Thiamet-G, an inhibitor for O-GlcNAcase that is responsible for removing GlcNAcylation, shows more prominent calcification. Increasing GlcNAcylation through O-GlcNAcase knockdown promotes VSMC calcification by promoting RUNX2 upregulation and AKT enhancement. They found two O-GlcNAcylation sites of AKT, T430, and T479, that can promote its phosphorylation and therefore enhance VSMC calcification. A site-directed mutagenesis study revealed decreased O-GlcNAcylation and AKT phosphorylation. This disrupts the AKT-mTORC2 binding, which subsequently decreases RUNX2 activity and VSMC calcification.

A recent study reported O-GlcNAcylation of a YAP (Yes-Associated Protein) [106]. YAP is involved in vascular calcification through VSMC phenotype regulation [107]. Evidence was also provided by another group using endothelial cells. Uemura et al. [108] demonstrated the role of YAP/TAZ in development of VC by promoting intramembranous ossification via BMP pathways in endothelial cells. Interestingly, perturbation of O-GlcNAcylation by OGT knockdown counteracts high phosphate-induced vascular calcification in CKD through autophagy activation by downregulating YAP in VSMC [80]. The same research group by $\mathrm{Xu}$ et al. [109] also reported that glycosylation by OGT increases phosphate-induced vascular calcification in CKD through autophagy inhibition. Mechanistically, OGT increases KEAP1 glycosylation and subsequently ubiquitinates NRF2, increasing its degradation through autophagy. NRF2 has been shown to induce autophagy, and autophagy is involved in the amelioration of VC [110,111].

The vascular calcification process and its factors are similar to that of bone ossification [112] involving MV, mineral deposition and hydroxyapatite formation [15]. Accumulating evidence highlights the importance of phosphate in ossification. Fibroblast growth factor 23 (FGF23) was found to be the main phosphate regulator. It is synthesized by osteocytes and released into circulation [113]. They act with a co-receptor, klotho, in the kidneys to regulate phosphate [114]. FGF23 is known to cause hypophosphate familial tumoral calcinosis [115]. GWAS revealed GALNT3 as a top novel gene affecting bone mineral density and fracture risk [116]. GALNT3 is one of the enzymes responsible for O-glycosylation initiation. Recent studies reported that GALNT3 is the only GALNTs family member which initiates glycosylation of FGF23 [73]. The mechanism of FGF23 glycosylation by GALNT3 has been extensively studied by de las Rivas et al. [81]. GALNT3 specifically O-glycosylates FGF23 at Thr178. It seems that FGF23 has a role in VC. Epidemiological studies have shown the correlation of FGF23 and vascular calcification $[117,118]$. This is supported by molecular study [119], however, controversy exists [120]. Correa et al. [40] demonstrated expression of FGF23 in human calcified vascular tissue. Although FGF23 is known to cooperate with klotho in inducing VC, Jimbo et al. [39] demonstrated that FGF23 alone is sufficient to induce VC, induced by phosphate. Although there are currently no studies that directly correlate the O-glycosylation of FGF23 and VC, the insight from the molecular studies regarding FGF23 glycosylation and FGF23's role in vascular calcification render correlation possible and warrant further study. 
Most of all, there is some interesting evidence that the master regulator of osteoblast differentiation, RUNX2, is also subject to glycosylation by O-GlcNac modification [121]. RUNX2 is a transcription factor that is regulated by cytokines, growth factors, and hormones, including TGF- $\beta$, BMP, FGF, sonic hedgehog, vitamin $\mathrm{D}_{3}$, and estrogen [122]. Nagel and Ball [123] enhance the O-GlcNAcylation of RUNX2 by inhibiting OGA (an enzyme responsible for O-GlcNac removal). This increases the RUNX2 transcriptional activity induced by BMP2/7. Moreover, the increase in O-GlcNAcylation resulted in increased levels and activity of the bone formation marker ALP. Although there is currently no evidence that directly correlates RUNX2 glycosylation and VC, it has been well established that increased VSMC RUNX2 leads to increased vascular calcification [82,83]. Therefore, modification of its glycosylation might influence VC.

\section{Proteoglycan and Vascular Calcification}

Proteoglycan has been well-known for its role in vascular disease [124]. The responseto-retention theory stated that the extracellular matrix (proteoglycan), which has a negative charge, binds to positively charged LDL, and causes atherosclerosis $[125,126]$. For one of the proteoglycan, GAG, biosynthesis involves serial and a few of the glycosylation steps [62]. The initiation (which involves O-glycosylation and N-glycosylation) and the elongation (which involves other glycosylation types) make GAG one of the complex forms of glycosylation. GAGs found in mammals are chondroitin sulfate, dermatan sulfate, and heparan sulfate [62]. Accumulating evidence has reported that proteoglycan is involved in VC.

Perlecan expression, one of heparan sulfate proteoglycan, is reported to decrease in aortic VC [84]. Purnomo et al. [85] demonstrated that GAG overproduction increases aortic calcification in murine CKD. They knocked-out EXTL2 to overexpress glycosaminoglycan and induced CKD by nephrectomy. They found that GAG overexpression induces VSMC's differentiation to osteoblastic-like cells via a BMP2/smad1/5/8 pathway. Another proteoglycan, hyaluronan, has been reported to decrease VC [86]. Mechanistically, it decreases ALP and the expression of bone-related molecules including RUNX2, BMP2, and MSX2. Therefore, it inhibits VSMC to osteoblast differentiation. Interestingly, hyaluronan is also subject to complex glycosylation. Hyaluronan synthesis can be inhibited by 4-methylumbelliferone (4MU), which can inhibit UDP-glucuronosyltransferase (UGT) and also compete with GlcNAc and GlcUA as a substrate for UGT [127].

Another member of proteoglycan, heparan sulfate, also showed its role in VC. A beautiful work by Borland et al. [87] demonstrated heparan sulfate in the extracellular domain of syndecan-4-regulating VSMC mineralization. Heparan sulfate biosynthesis involves several glycosylation enzymes, the most important being exostosin glycosyltransferase 1 (EXT1). Knocking down EXT1 increases VSMC mineralization. Mechanistically, the reduced heparan sulfate expression in syndecan 4's extracellular domain causes a decrease in FGF2-induced AKT activation by decreasing FGF2-PKC $\alpha$ interaction. Therefore, heparan sulfate may be required to decrease VC. The mechanism of VC and how glycosylation affects it is illustrated in the Figure 1. 


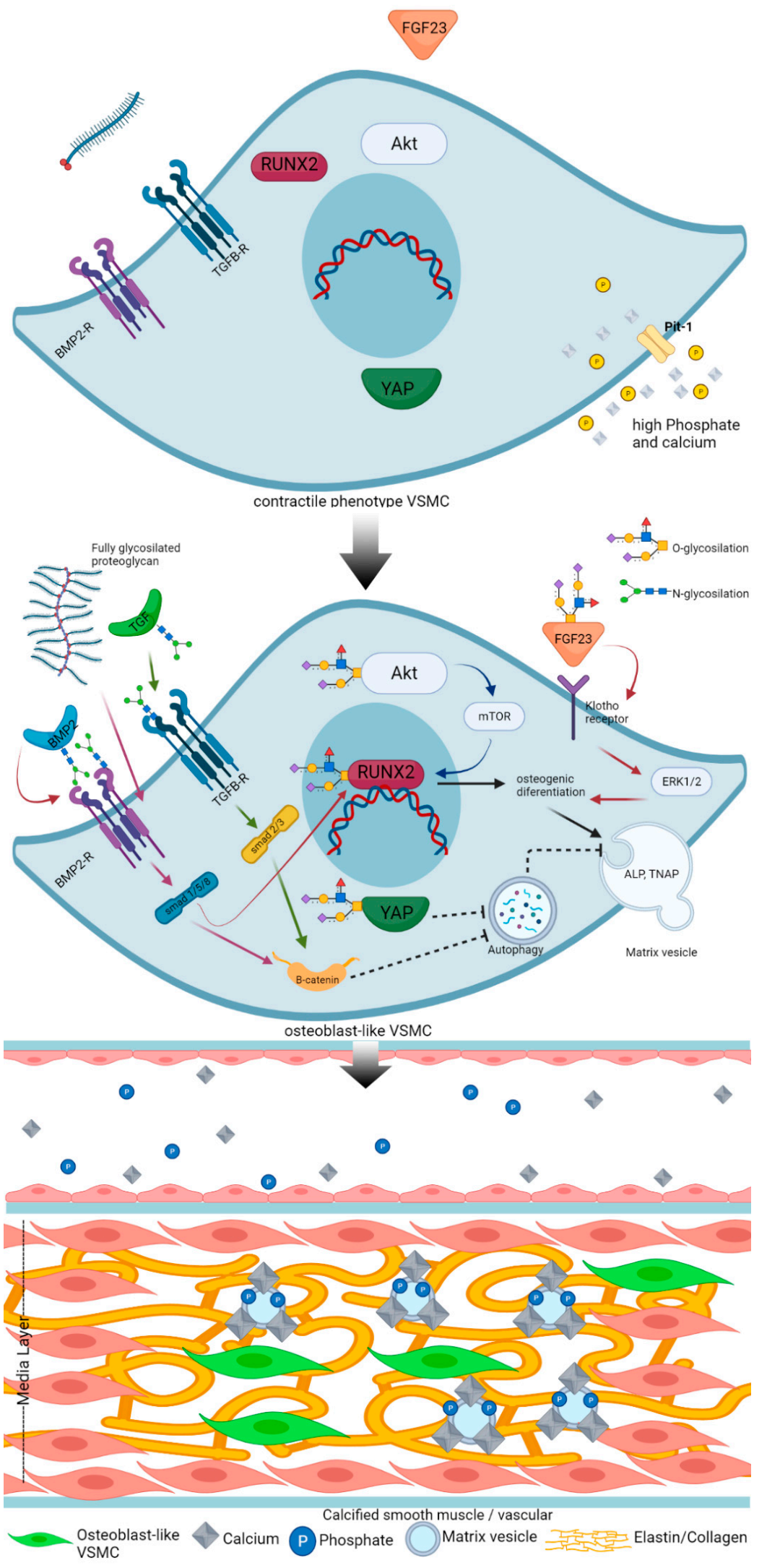

Figure 1. Proposed mechanism of how glycosylation of regulatory factors affects vascular calcification. Mechanism of vascular calcification involves loss of inhibitor and gain inducer. In the condition rich of phosphate and calcium, the VSMC transdifferentiates into osteoblast-like cell (top panel). Calcification 
inducers such as BMP2, FGF23, and ALP were recently reported to be modified by glycosylation. Even the master regulator of calcification, RUNX2, is also reported to be modified by glycosylation. The activation of an osteogenic program by RUNX2 subsequently induces formation and secretion of MVs. Secreted MVs contain enzymes that support calcification (e.g., ALP, (tissue nonspecific alkaline phosphatase (TNAP), which are potent calcification inducers). MVs serve as nidus for hydroxyapatite formation. Matrix vesicle formation is interfered by autophagy. Autophagy is considered to decrease vascular calcification. BMP2 increases calcification through inhibition of autophagy. BMP2 secretion is modified by glycosylation. Fully glycosylated proteoglycan induces VC via a BMP2-BMP2R-smad1/5/8 pathway. TGF $\beta$-TGF $\beta R$ induces calcification through smad2/3- $\beta$-catenin. This pathway inhibits autophagy, which eventually increases calcification. FGF23 secretion requires glycosylation by GALNT3. FGF23-klotho binding in VSMC activates an osteogenic program through ERK1/2. Overall, the increasing glycosylation will stabilize calcification inducers and eventually induce vascular calcification (middle and bottom panel). This figure is compiled from references $[26,39,77,79,80,83,85,91,93,95,108,110,128-131]$. The illustration was Created with BioRender.com.

\section{Conclusions and Perspective}

The vascular calcification process resembles bone ossification, including the regulatory factors involved. The emerging evidence shows the importance of glycosylation in the development of disease. Numerous studies report the glycosylation of regulatory factors of VC and their various effects in VC. Here, we summarized the target of glycosylation in association with vascular calcification. This work will open future research regarding glycosylation and vascular calcification.

Author Contributions: Conceptualization, A.N.M. and P.-Y.L.; writing—original draft preparation, A.N.M.; writing-review and editing, A.N.M., M.S.R. and P.-Y.L.; visualization, A.N.M.; supervision, M.S.R. and P.-Y.L.; project administration, P.-Y.L.; funding acquisition, P.-Y.L. All authors have read and agreed to the published version of the manuscript.

Funding: This study was supported by grants 109-2634-F-006-023 and 108-2314-B-006-098-MY3 from the Ministry of Science and Technology of Taiwan, and grants D108-G2512, D109-G4803, D109-G4804 and D109-G2512 from Higher Education Sprout Project, Ministry of Education to the Headquarters of University Advancement at National Cheng Kung University.

Conflicts of Interest: The authors declared no conflict of interest.

\section{References}

1. Wilson, P.W.F.; Kauppila, L.I.; O’Donnell, C.J.; Kiel, D.P.; Hannan, M.; Polak, J.M.; Cupples, L.A. Abdominal aortic calcific deposits are an important predictor of vascular morbidity and mortality. Circulation 2001, 103, 1529-1534. [CrossRef]

2. Budoff, M.J.; Shaw, L.J.; Liu, S.T.; Weinstein, S.R.; Mosler, T.P.; Tseng, P.H.; Flores, F.R.; Callister, T.Q.; Raggi, P.; Berman, D.S. Long-Term Prognosis Associated With Coronary Calcification. Observations From a Registry of 25,253 Patients. J. Am. Coll. Cardiol. 2007, 49, 1860-1870. [CrossRef]

3. Garrison, L.P.; Lewin, J.; Young, C.H.; Généreux, P.; Crittendon, J.; Mann, M.R.; Brindis, R.G. The clinical and cost burden of coronary calcification in a Medicare cohort: An economic model to address under-reporting and misclassification. Cardiovasc. Revascularization Med. 2015, 16, 406-412. [CrossRef]

4. Hofmann Bowman, M.A.; McNally, E.M. Genetic Pathways of Vascular Calcification. Trends Cardiovasc. Med. 2012, 22, 93-98. [CrossRef]

5. Lee, D. Vascular calcification: Inducers and inhibitors. Mater. Sci. Eng. B Solid-State Mater. Adv. Technol. 2011, 176, 1133-1141. [CrossRef]

6. Ngai, D.; Lino, M.; Bendeck, M.P. Cell-Matrix Interactions and Matricrine Signaling in the Pathogenesis of Vascular Calcification. Front. Cardiovasc. Med. 2018, 5, 1-16. [CrossRef]

7. Lee, S.J.; Lee, I.K.; Jeon, J.H. Vascular calcification-New insights into its mechanism. Int. J. Mol. Sci. 2020, 21, 2685. [CrossRef] [PubMed]

8. Durham, A.L.; Speer, M.Y.; Scatena, M.; Giachelli, C.M.; Shanahan, C.M. Role of smooth muscle cells in vascular calcification: Implications in atherosclerosis and arterial stiffness. Cardiovasc. Res. 2018, 114, 590-600. [CrossRef] [PubMed]

9. Shroff, R.; Long, D.A.; Shanahan, C. Mechanistic insights into vascular calcification in CKD. J. Am. Soc. Nephrol. 2013, 24, 179-189. [CrossRef]

10. Yang, P.; Troncone, L.; Augur, Z.M.; Kim, S.S.J.; McNeil, M.E.; Yu, P.B. The role of bone morphogenetic protein signaling in vascular calcification. Bone 2020, 141, 115542. [CrossRef] [PubMed] 
11. Nakahara, T.; Dweck, M.R.; Narula, N.; Pisapia, D.; Narula, J.; Strauss, H.W. Coronary Artery Calcification: From Mechanism to Molecular Imaging. JACC Cardiovasc. Imaging 2017, 10, 582-593. [CrossRef] [PubMed]

12. Maehara, A.; Stone, G.W.; Généreux, P. Coronary Artery Calcification Pathogenesis and Prognostic Implications. J. Am. Coll. Cardiol. 2014, 63, 1703-1714. [CrossRef]

13. Leopold, J.A. Vascular calcification: Mechanisms of vascular smooth muscle cell calcification. Trends Cardiovasc. Med. 2015, 25, 267-274. [CrossRef] [PubMed]

14. Ho, C.Y.; Shanahan, C.M. Medial Arterial Calcification: An Overlooked Player in Peripheral Arterial Disease. Arterioscler. Thromb. Vasc. Biol. 2016, 36, 1475-1482. [CrossRef]

15. Demer, L.L.; Tintut, Y. Inflammatory, metabolic, and genetic mechanisms of vascular calcification. Arterioscler. Thromb. Vasc. Biol. 2014, 34, 715-723. [CrossRef]

16. Giachelli, C.M. Vascular calcification mechanisms. J. Am. Soc. Nephrol. 2004, 15, 2959-2964. [CrossRef] [PubMed]

17. Johnson, R.C.; Leopold, J.A.; Loscalzo, J. Vascular calcification: Pathobiological mechanisms and clinical implications. Circ. Res. 2006, 99, 1044-1059. [CrossRef]

18. Sage, A.P.; Tintut, Y.; Demer, L.L. Regulatory mechanisms in vascular calcification. Nat. Rev. Cardiol. 2010, 7, 528-536. [CrossRef] [PubMed]

19. Westenfeld, R.; Schäfer, C.; Krüger, T.; Haarmann, C.; Schurgers, L.J.; Reutelingsperger, C.; Ivanosvski, O.; Drueke, T.; Massy, Z.A.; Ketteler, M.; et al. Fetuin-A protects against atherosclerotic calcification in CKD. J. Am. Soc. Nephrol. 2009, 20, 1264-1274. [CrossRef]

20. Yamada, S.; Tokumoto, M.; Tsuruya, K.; Tatsumoto, N.; Noguchi, H.; Kitazono, T.; Ooboshi, H. Fetuin-A decrease induced by a low-protein diet enhances vascular calcification in uremic rats with hyperphosphatemia. Am. J. Physiol.-Ren. Physiol. 2015, 309, F744-F754. [CrossRef] [PubMed]

21. Uedono, H.; Mori, K.; Ochi, A.; Nakatani, S.; Miki, Y.; Tsuda, A.; Morioka, T.; Nagata, Y.; Imanishi, Y.; Shoji, T.; et al. Effects of fetuin-A-containing calciprotein particles on posttranslational modifications of fetuin-A in HepG2 cells. Sci. Rep. 2021, 11, 1-9. [CrossRef]

22. Jahnen-Dechent, W.; Heiss, A.; Schäfer, C.; Ketteler, M. Fetuin-A regulation of calcified matrix metabolism. Circ. Res. 2011, 108, 1494-1509. [CrossRef] [PubMed]

23. Chen, N.X.; O'Neill, K.D.; Chen, X.; Duan, D.; Wang, E.; Sturek, M.S.; Edwards, J.M.; Moe, S.M. Fetuin-A uptake in bovine vascular smooth muscle cells is calcium dependent and mediated by annexins. Am. J. Physiol.-Ren. Physiol. 2007, 292, 599-606. [CrossRef] [PubMed]

24. Chang, W.T.; Chen, P.S.; Chen, P.W.; Tsai, L.M.; Liu, P.Y. Fetuin A adds prognostic value for cardiovascular outcomes among patients with coronary artery disease with moderate calcification. Int. J. Cardiol. 2015, 185, 159-161. [CrossRef] [PubMed]

25. Chang, W.T.; Tsai, W.C.; Wu, C.H.; Lee, Y.W.; Tai, Y.L.; Li, Y.H.; Tsai, L.M.; Chen, J.H.; Liu, P.Y. Fetuin-A as a predicator of sarcopenic left ventricular dysfunction. Sci. Rep. 2015, 5, 1-11. [CrossRef]

26. Hruska, K.A.; Mathew, S.; Saab, G. Bone morphogenetic proteins in vascular calcification. Circ. Res. 2005, 97, 105-114. [CrossRef]

27. Villa-Bellosta, R.; Wang, X.; Millán, J.L.; Dubyak, G.R.; O’Neill, W.C. Extracellular pyrophosphate metabolism and calcification in vascular smooth muscle. Am. J. Physiol.-Heart Circ. Physiol. 2011, 301, 61-68. [CrossRef]

28. Yin, X.; Zhou, C.; Li, J.; Liu, R.; Shi, B.; Yuan, Q.; Zou, S. Autophagy in bone homeostasis and the onset of osteoporosis. Bone Res. 2019, 7, 1-16. [CrossRef]

29. Peng, Y.Q.; Xiong, D.; Lin, X.; Cui, R.R.; Xu, F.; Zhong, J.Y.; Zhu, T.; Wu, F.; Mao, M.Z.; Liao, X.B.; et al. Oestrogen Inhibits Arterial Calcification by Promoting Autophagy. Sci. Rep. 2017, 7, 1-14. [CrossRef]

30. Liang, J.; Huang, J.; He, W.; Shi, G.; Chen, J. $\beta$-Hydroxybutyric Inhibits Vascular Calcification via Autophagy Enhancement in Models Induced by High Phosphate. Front. Cardiovasc. Med. 2021, 8, 1-10. [CrossRef]

31. Poniatowski, L.A.; Wojdasiewicz, P.; Gasik, R.; Szukiewicz, D. Transforming growth factor beta family: Insight into the role of growth factors in regulation of fracture healing biology and potential clinical applications. Mediat. Inflamm. 2015, 1-17. [CrossRef]

32. Watson, K.E.; Bostrom, K.; Ravindranath, R.; Lam, T.; Norton, B.; Demer, L.L. Osteoblast-like Vascular Cells to Calcify. J. Clin. Investig. 1994, 93, 2106-2113. [CrossRef]

33. Jian, B.; Narula, N.; Li, Q.Y.; Mohler, E.R.; Levy, R.J. Progression of aortic valve stenosis: TGF- $\beta 1$ is present in calcified aortic valve cusps and promotes aortic valve interstitial cell calcification via apoptosis. Ann. Thorac. Surg. 2003, 75, 457-465. [CrossRef]

34. Shimokado, A.; Sun, Y.; Nakanishi, M.; Sato, F.; Oikawa, K.; Akasaka, T.; Muragaki, Y. Smad3 plays an inhibitory role in phosphate-induced vascular smooth muscle cell calcification. Exp. Mol. Pathol. 2014, 97, 458-464. [CrossRef] [PubMed]

35. Wu, M.; Chen, G.; Li, Y.P. TGF- $\beta$ and BMP signaling in osteoblast, skeletal development, and bone formation, homeostasis and disease. Bone Res. 2016, 4, 1-21. [CrossRef] [PubMed]

36. Zhao, J.; Warburton, D. Matrix Gla protein gene expression is induced by transforming growth factor- $\beta$ in embryonic lung culture Am. J. Physiol.-Lung Cell. Mol. Physiol. 1997, 273, L282-L287. [CrossRef]

37. Guerrero, F.; Herencia, C.; Almadén, Y.; Martínez-Moreno, J.M.; Montes De Oca, A.; Rodriguez-Ortiz, M.E.; Diaz-Tocados, J.M.; Canalejo, A.; Florio, M.; Lopez, I.; et al. TGF- $\beta$ prevents phosphate-induced osteogenesis through inhibition of BMP and Wnt/ $\beta$-catenin pathways. PLoS ONE 2014, 9, e89179. [CrossRef]

38. Halling Linder, C.; Narisawa, S.; Millán, J.L.; Magnusson, P. Glycosylation differences contribute to distinct catalytic properties among bone alkaline phosphatase isoforms. Bone 2009, 45, 987-993. [CrossRef] 
39. Jimbo, R.; Kawakami-Mori, F.; Mu, S.; Hirohama, D.; Majtan, B.; Shimizu, Y.; Yatomi, Y.; Fukumoto, S.; Fujita, T.; Shimosawa, T. Fibroblast growth factor 23 accelerates phosphate-induced vascular calcification in the absence of Klotho deficiency. Kidney Int. 2014, 85, 1103-1111. [CrossRef] [PubMed]

40. Donate-Correa, J.; Martín-Núñez, E.; Hernández-Carballo, C.; Ferri, C.; Tagua, V.G.; Delgado-Molinos, A.; Lopez-Castillo, A.; Rodriguez-Ramoz, S.; Cerro-Lopez, P.; Lopez-Tarruella, V.C.; et al. Fibroblast growth factor 23 expression in human calcified vascular tissues. Aging 2019, 11, 7899-7913. [CrossRef]

41. Alves, R.D.A.M.; Eijken, M.; van de Peppel, J.; van Leeuwen, J.P.T.M. Calcifying vascular smooth muscle cells and osteoblasts: Independent cell types exhibiting extracellular matrix and biomineralization-related mimicries. BMC Genomics 2014, 15, 1-14. [CrossRef]

42. Chellan, B.; Rojas, E.; Zhang, C.; Hofmann Bowman, M.A. Enzyme-modified non-oxidized LDL (ELDL) induces human coronary artery smooth muscle cell transformation to a migratory and osteoblast-like phenotype. Sci. Rep. 2018, 8, 1-14. [CrossRef]

43. Collett, G.D.M.; Canfield, A.E. Angiogenesis and pericytes in the initiation of ectopic calcification. Circ. Res. 2005, 96, 930-938. [CrossRef] [PubMed]

44. Xu, J.; Li, D.; Hsu, C.Y.; Tian, Y.; Zhang, L.; Wang, Y.; Tower, R.J.; Chang, L.; Meyers, C.A.; Gao, Y.; et al. Comparison of skeletal and soft tissue pericytes identifies CXCR4+ bone forming mural cells in human tissues. Bone Res. 2020, 8, 1-14. [CrossRef]

45. Doehring, L.C.; Heeger, C.; Aherrahrou, Z.; Kaczmarek, P.M.; Erdmann, J.; Schunkert, H.; Ehlers, E.M. Myeloid CD34+CD13+ precursor cells transdifferentiate into chondrocyte-like cells in atherosclerotic intimal calcification. Am. J. Pathol. 2010, 177, 473-480. [CrossRef]

46. Pinho, S.S.; Reis, C.A. Glycosylation in cancer: Mechanisms and clinical implications. Nat. Rev. Cancer 2015, 15, 540-555. [CrossRef] [PubMed]

47. van Tol, W.; Wessels, H.; Lefeber, D.J. O-glycosylation disorders pave the road for understanding the complex human Oglycosylation machinery. Curr. Opin. Struct. Biol. 2019, 56, 107-118. [CrossRef] [PubMed]

48. Schjoldager, K.T.; Narimatsu, Y.; Joshi, H.J.; Clausen, H. Global view of human protein glycosylation pathways and functions. Nat. Rev. Mol. Cell Biol. 2020, 21, 729-749. [CrossRef]

49. Bektas, M.; Rubenstein, D.S. The role of intracellular protein O-glycosylation in cell adhesion and disease. J. Biomed. Res. 2011, 25, 227-236. [CrossRef]

50. Gamblin, D.P.; Scanlan, E.M.; Davis, B.G. Glycoprotein synthesis: An update. Chem. Rev. 2009, 109, 131-163. [CrossRef] [PubMed]

51. Varki, A. Biological roles of glycans. Glycobiology 2017, 27, 3-49. [CrossRef]

52. Moremen, K.W.; Haltiwanger, R.S. Emerging structural insights into glycosyltransferase-mediated synthesis of glycans. Nat. Chem. Biol. 2019, 15, 853-864. [CrossRef]

53. Clerc, F.; Reiding, K.R.; Jansen, B.C.; Kammeijer, G.S.M.; Bondt, A.; Wuhrer, M. Human plasma protein N-glycosylation. Glycoconj. J. 2016, 33, 309-343. [CrossRef] [PubMed]

54. Spiro, R.G. Protein glycosylation: Nature, distribution, enzymatic formation, and disease implications of glycopeptide bonds. Glycobiology 2002, 12, 43R-56R. [CrossRef]

55. Wu, Y.M.; Liu, C.H.; Hu, R.H.; Huang, M.J.; Lee, J.; Chen, C.H.; Huang, J.; Lai, H.S.; Lee, P.H.; Hsu, W.M.; et al. Mucin glycosylating enzyme GALNT2 regulates the malignant character of hepatocellular carcinoma by modifying the EGF receptor. Cancer Res. 2011, 71, 7270-7279. [CrossRef] [PubMed]

56. Ferreira, I.G.; Pucci, M.; Venturi, G.; Malagolini, N.; Chiricolo, M.; Dall'Olio, F. Glycosylation as a main regulator of growth and death factor receptors signaling. Int. J. Mol. Sci. 2018, 19, 580. [CrossRef]

57. Bagdonaite, I.; Pallesen, E.M.; Ye, Z.; Vakhrushev, S.Y.; Marinova, I.N.; Nielsen, M.I.; Kramer, S.H.; Pedersen, S.F.; Joshi, H.J.; Bennet, E.P.; et al. O-glycan initiation directs distinct biological pathways and controls epithelial differentiation. EMBO Rep. 2020, 21, 1-17. [CrossRef] [PubMed]

58. Klaver, E.; Zhao, P.; May, M.; Flanagan-Steet, H.; Freeze, H.H.; Gilmore, R.; Wells, L.; Contessa, J.; Steet, R. Selective inhibition of $\mathrm{N}$-linked glycosylation impairs receptor tyrosine kinase processing. DMM Dis. Models Mech. 2019, 12, dmm039602. [CrossRef]

59. Steentoft, C.; Vakhrushev, S.Y.; Joshi, H.J.; Kong, Y.; Vester-Christensen, M.B.; Schjoldager, K.T.B.G.; Lavrsen, K.; Dabelsteen, S.; Pedersen, N.B.; Marcos-Silva, L.; et al. Precision mapping of the human O-GalNAc glycoproteome through SimpleCell technology. EMBO J. 2013, 32, 1478-1488. [CrossRef]

60. Tajadura-Ortega, V.; Gambardella, G.; Skinner, A.; Halim, A.; Van Coillie, J.; Schjoldager, K.T.B.G.; Beatson, R.; Graham, R.; Achkova, D.; Taylor-Papadimitriou, J.; et al. O-linked mucin-type glycosylation regulates the transcriptional programme downstream of EGFR. Glycobiology 2021, 31, 200-210. [CrossRef]

61. Tian, E.; Hoffman, M.P.; Ten Hagen, K.G. O-glycosylation modulates integrin and FGF signalling by influencing the secretion of basement membrane components. Nat. Commun. 2012, 3, 1-10. [CrossRef]

62. Prydz, K.; Dalen, K.T. Synthesis and sorting of proteoglycans. J. Cell Sci. 2000, 113, 193-205. [CrossRef]

63. Mikami, T.; Kitagawa, H. Biosynthesis and function of chondroitin sulfate. Biochim. Biophys. Acta-Gen. Subj. 2013, 1830, 4719-4733. [CrossRef]

64. Reily, C.; Stewart, T.J.; Renfrow, M.B.; Novak, J. Glycosylation in health and disease. Nat. Rev. Nephrol. 2019, 15, 346-366. [CrossRef] 
65. Freitas, D.; Campos, D.; Gomes, J.; Pinto, F.; Macedo, J.A.; Matos, R.; Mereiter, S.; Pinto, M.T.; Polonia, A.; Gartner, F.; et al. Oglycans truncation modulates gastric cancer cell signaling and transcription leading to a more aggressive phenotype. EBioMedicine 2019, 40, 349-362. [CrossRef] [PubMed]

66. Costa, R.; Remigante, A.; Civello, D.A.; Bernardinelli, E.; Szabó, Z.; Morabito, R.; Marino, A.; Sarikas, A.; Patsch, W.; Paulmichi, M.; et al. O-GlcNAcylation Suppresses the Ion Current IClswell by Preventing the Binding of the Protein ICln to $\alpha$-Integrin. Front. Cell Dev. Biol. 2020, 8, 1-23. [CrossRef]

67. Pirillo, A.; Svecla, M.; Catapano, A.L.; Holleboom, A.G.; Norata, G.D. Impact of protein glycosylation on lipoprotein metabolism and atherosclerosis. Cardiovasc. Res. 2021, 117, 1033-1045. [CrossRef] [PubMed]

68. Holleboom, A.G.; Karlsson, H.; Lin, R.S.; Beres, T.M.; Sierts, J.A.; Herman, D.S.; Stroes, E.S.G.; Aerts, J.M.; Kastelein, J.J.P.; Motazacker, M.M.; et al. Heterozygosity for a loss-of-function mutation in GALNT2 improves plasma triglyceride clearance in man. Cell Metab. 2011, 14, 811-818. [CrossRef]

69. Khetarpal, S.A.; Schjoldager, K.T.; Christoffersen, C.; Raghavan, A.; Edmondson, A.C.; Reutter, H.M.; Ahmed, B.; Ouazzani, R.; Peloso, G.M.; Vitali, C.; et al. Loss of Function of GALNT2 Lowers High-Density Lipoproteins in Humans, Nonhuman Primates, and Rodents. Cell Metab. 2016, 24, 234-245. [CrossRef] [PubMed]

70. Shrikhande, G.V.; Scali, S.T.; da Silva, C.G.; Damrauer, S.M.; Csizmadia, E.; Putheti, P.; Matthey, M.; Arjoon, R.; Patel, R.; Siracuse, J.J.; et al. O-Glycosylation regulates ubiquitination and degradation of the anti-inflammatory protein A20 to accelerate atherosclerosis in diabetic ApoE-null mice. PLoS ONE 2010, 5, e14240. [CrossRef]

71. Liu, Y.-W.; Huang, M.-S.; Hsu, L.-W.; Chang, H.-Y.; Lee, C.-H.; Lee, C.-Y.; Chen, D.P.; Li, Y.H.; Chao, T.H.; Su, P.F.; et al. Genetic risk model for instent restenosis of second and third generation drug eluting stents. IScience. 2021, 24. in press. [CrossRef]

72. Adhikara, I.M.; Yagi, K.; Mayasari, D.S.; Suzuki, Y.; Ikeda, K.; Ryanto, G.R.T.; Sasaki, N.; Rikitake, Y.; Nadanaka, S.; Kitagawa, $\mathrm{H}$; ; et al. Chondroitin sulfate $\mathrm{N}$-acetylgalactosaminyltransferase- 2 impacts foam cell formation and atherosclerosis by altering macrophage glycosaminoglycan chain. Arterioscler. Thromb. Vasc. Biol. 2021, 41, 1076-1091. [CrossRef]

73. Kato, K.; Jeanneau, C.; Tarp, M.A.; Benet-Pagès, A.; Lorenz-Depiereux, B.; Bennett, E.P.; Mandel, U.; Strom, T.M.; Clausen, H. Polypeptide GalNAc-transferase T3 and familial tumoral calcinosis: Secretion of fibroblast growth factor 23 requires Oglycosylation. J. Biol. Chem. 2006, 281, 18370-18377. [CrossRef] [PubMed]

74. Yoshida, C.A.; Kawane, T.; Moriishi, T.; Purushothaman, A.; Miyazaki, T.; Komori, H.; Mori, M.; Qin, X.; Hashimoto, A.; Sugahara, K.; et al. Overexpression of Galnt3 in chondrocytes resulted in dwarfism due to the increase of mucin-type O-glycans and reduction of glycosaminoglycans. J. Biol. Chem. 2014, 289, 26584-26596. [CrossRef]

75. Andrés-Bergós, J.; Tardio, L.; Larranaga-Vera, A.; Gómez, R.; Herrero-Beaumont, G.; Largo, R. The increase in O-linked Nacetylglucosamine protein modification stimulates chondrogenic differentiation both in vitro and in vivo. J. Biol. Chem. 2012, 287, 33615-33628. [CrossRef] [PubMed]

76. Siddals, K.W.; Allen, J.; Sinha, S.; Canfield, A.E.; Kalra, P.A.; Martin Gibson, J. Apposite insulin-like growth factor (IGF) receptor glycosylation is critical to the maintenance of vascular smooth muscle phenotype in the presence of factors promoting osteogenic differentiation and mineralization. J. Biol. Chem. 2011, 286, 16623-16630. [CrossRef] [PubMed]

77. Hang, Q.; Zhou, Y.; Hou, S.; Zhang, D.; Yang, X.; Chen, J.; Ben, Z.; Cheng, C.; Shen, A. Asparagine-linked glycosylation of bone morphogenetic protein-2 is required for secretion and osteoblast differentiation. Glycobiology 2014, 24, 292-304. [CrossRef]

78. Wen, X.; Liu, A.; Yu, C.; Wang, L.; Zhou, M.; Wang, N.; Fang, M.; Wang, W.; Lin, H. Inhibiting post-translational core fucosylation prevents vascular calcification in the model of uremia. Int. J. Biochem. Cell Biol. 2016, 79, 69-79. [CrossRef] [PubMed]

79. Heath, J.M.; Sun, Y.; Yuan, K.; Bradley, W.E.; Litovsky, S.; Dell'Italia, L.J.; Catham, J.J.; Wu, H.; Chen, Y. Activation of AKT by O-linked N-Acetylglucosamine induces vascular calcification in diabetes mellitus. Circ. Res. 2014, 114, 1094-1102. [CrossRef]

80. Xu, T.H.; Sheng, Z.; Li, Y.; Qiu, X.; Tian, B.; Yao, L. OGT knockdown counteracts high phosphate-induced vascular calcification in chronic kidney disease through autophagy activation by downregulating YAP. Life Sci. 2020, 261, 118121. [CrossRef]

81. de las Rivas, M.; Paul Daniel, E.J.; Narimatsu, Y.; Compañón, I.; Kato, K.; Hermosilla, P.; Thureau, A.; Ceballos-Laita, L.; Coelho, H.; Bernado, P.; et al. Molecular basis for fibroblast growth factor 23 O-glycosylation by GalNAc-T3. Nat. Chem. Biol. 2020, 16, 351-360. [CrossRef]

82. Sun, Y.; Byon, C.H.; Yuan, K.; Chen, J.; Mao, X.; Heath, J.M.; Javed, A.; Zhang, K.; Anderson, P.G.; Chen, Y. Smooth muscle cell-specific runx2 deficiency inhibits vascular calcification. Circ. Res. 2012, 111, 543-552. [CrossRef]

83. Lin, M.E.; Chen, T.; Leaf, E.M.; Speer, M.Y.; Giachelli, C.M. Runx2 Expression in Smooth Muscle Cells Is Required for Arterial Medial Calcification in Mice. Am. J. Pathol. 2015, 185, 1958-1969. [CrossRef] [PubMed]

84. Shibata, M.; Shigematsu, T.; Hatamura, I.; Saji, F.; Mune, S.; Kunimoto, K.; Hanba, Y.; Shiizaki, K.; Sakaguchi, T.; Negi, S. Reduced expression of perlecan in the aorta of secondary hyperparathyroidism model rats with medial calcification. Ren. Fail. 2010, 32, 214-223. [CrossRef] [PubMed]

85. Purnomo, E.; Emoto, N.; Nugrahaningsih, D.A.A.; Nakayama, K.; Yagi, K.; Heiden, S.; Nadanaka, S.; Kitagawa, H.; Hirata, K. Glycosaminoglycan overproduction in the aorta increases aortic calcification in murine chronic kidney disease. J. Am. Heart Assoc. 2013, 2, 1-18. [CrossRef] [PubMed]

86. Kong, Y.; Liang, Q.; Chen, Y.; Yang, P.; Liu, X.; Li, Y.; Feng, S.; Wu, J.; Liu, W.; Tang, J.; et al. Hyaluronan negatively regulates vascular calcification involving BMP2 signaling. Lab Investig. 2018, 98, 1320-1332. [CrossRef] 
87. Borland, S.J.; Morris, T.G.; Borland, S.C.; Morgan, M.R.; Francis, S.E.; Merry, C.L.R.; Canfield, A.E. Regulation of vascular smooth muscle cell calcification by syndecan-4/FGF-2/PKC $\alpha$ signalling and cross-talk with TGF $\beta$. Cardiovasc. Res. 2017, 113, 1639-1652. [CrossRef]

88. Li, X.; Yang, H.Y.; Giachelli, C.M. BMP-2 promotes phosphate uptake, phenotypic modulation, and calcification of human vascular smooth muscle cells. Atherosclerosis 2008, 199, 271-277. [CrossRef]

89. Rahman, M.S.; Akhtar, N.; Jamil, H.M.; Banik, R.S.; Asaduzzaman, S.M. TGF- $\beta$ /BMP signaling and other molecular events: Regulation of osteoblastogenesis and bone formation. Bone Res. 2015, 3, 1-20. [CrossRef] [PubMed]

90. Van De Watering, F.C.J.; Van Den Beucken, J.J.J.P.; Van Der Woning, S.P.; Briest, A.; Eek, A.; Qureshi, H.; Winnubst, L.; Boerman, O.C.; Jansen, J.A. Non-glycosylated BMP-2 can induce ectopic bone formation at lower concentrations compared to glycosylated BMP-2. J. Control. Release 2012, 159, 69-77. [CrossRef]

91. Lowery, J.W.; Amich, J.M.; Andonian, A.; Rosen, V. N-linked glycosylation of the bone morphogenetic protein receptor type 2 (BMPR2) enhances ligand binding. Cell Mol. Life Sci. 2014, 71, 3165-3172. [CrossRef]

92. Sako, D.; Grinberg, A.V.; Liu, J.; Davies, M.V.; Castonguay, R.; Maniatis, S.; Andreucci, A.J.; Pobre, E.G.; Tomkinson, K.N.; Monell, T.E.; et al. Characterization of the ligand binding functionality of the extracellular domain of activin receptor type IIB. J. Biol. Chem. 2010, 285, 21037-21048. [CrossRef] [PubMed]

93. Kanno, Y.; Into, T.; Lowenstein, C.J.; Matsushita, K. Nitric oxide regulates vascular calcification by interfering with TGF- $\beta$ signalling. Cardiovasc. Res. 2008, 77, 221-230. [CrossRef] [PubMed]

94. Sha, X.; Brunner, A.M.; Purchio, A.F.; Gentry, L.E. Transforming growth factor $\beta 1$, Importance of glycosylaytion and acidic proteases for processing and secretion. Mol. Endocrinol. 1989, 3, 1090-1098. [CrossRef] [PubMed]

95. Watanabe, S.; Misawa, M.; Matsuzaki, T.; Sakurai, T.; Muramatsu, T.; Sato, M. A novel glycosylation signal regulates transforming growth factor receptors as evidenced by endo-Galactosidase C expression in rodent cells. Glycobiology 2011, 21, 482-492. [CrossRef] [PubMed]

96. Lin, Y.H.; Franc, V.; Heck, A.J.R. Similar Albeit Not the Same: In-Depth Analysis of Proteoforms of Human Serum, Bovine Serum, and Recombinant Human Fetuin. J. Proteome Res. 2018, 17, 2861-2869. [CrossRef] [PubMed]

97. Smith, E.R.; Ford, M.L.; Tomlinson, L.A.; Rajkumar, C.; McMahon, L.P.; Holt, S.G. Phosphorylated fetuin-A-containing calciprotein particles are associated with aortic stiffness and a procalcific milieu in patients with pre-dialysis CKD. Nephrol. Dial. Transpl. 2012, 27, 1957-1966. [CrossRef] [PubMed]

98. Bellia, C.; Agnello, L.; Lo Sasso, B.; Milano, S.; Bivona, G.; Scazzone, C.; Pivetti, A.; Novo, G.; Palermo, C.; Bonomo, V.; et al. Fetuin-A is Associated to Serum Calcium and AHSG T256S Genotype but Not to Coronary Artery Calcification. Biochem. Genet. 2016, 54, 222-231. [CrossRef]

99. Mohammadi-Noori, E.; Salehi, N.; Mozafari, H.; Elieh Ali Komi, D.; Saidi, M.; Bahrehmand, F.; Vaisi-Raygani, A.; Elahirad, S.; Moini, A.; Kiani, A. Association of AHSG gene polymorphisms with serum Fetuin-A levels in individuals with cardiovascular calcification in west of Iran. Mol. Biol. Rep. 2020, 47, 1809-1820. [CrossRef]

100. Lin, Y.H.; Zhu, J.; Meijer, S.; Franc, V.; Heck, A.J.R. Glycoproteogenomics: A frequent gene polymorphism affects the glycosylation pattern of the human serum fetuin/ $\alpha$-2-HS-Glycoprotein. Mol. Cell Proteom. 2019, 18, 1479-1490. [CrossRef]

101. Nielsen, M.I.; Stegmayr, J.; Grant, O.C.; Yang, Z.; Nilsson, U.J.; Boos, I.; Carlsson, M.C.; Woods, R.J.; Unverzagt, C.; Leffler, H.; et al. Galectin binding to cells and glycoproteins with genetically modified glycosylation reveals galectin-glycan specificities in a natural context. J. Biol. Chem. 2018, 293, 20249-20262. [CrossRef]

102. Chen, P.W.; Hsu, L.W.; Chang, H.Y.; Huang, T.C.; Yu, J.R.; Liao, H.Y.; Lee, C.H.; Liu, P.Y. Elevated platelet galectin-3 and rho-associated protein kinase activity are associated with hemodialysis arteriovenous shunt dysfunction among subjects with diabetes mellitus. Biomed. Res. Int. 2019. [CrossRef]

103. Iacobini, C.; Fantauzzi, C.B.; Pugliese, G.; Menini, S. Role of galectin-3 in bone cell differentiation, bone pathophysiology and vascular osteogenesis. Int. J. Mol. Sci. 2017, 18, 2481. [CrossRef]

104. Zhang, Q.; Yin, K.; Ni, Z. Galectin-3 and abdominal aortic calcification in patients on hemodialysis. Vasc. Med. 2020, 25, 575-576. [CrossRef]

105. Ibarrola, J.; Martínez-Martínez, E.; Sádaba, J.R.; Arrieta, V.; García-Peña, A.; Álvarez, V.; Fernandez-Celiz, A.; Gainza, A.; Rossignol, P.; Ramos, V.C.; et al. Beneficial effects of galectin-3 blockade in vascular and aortic valve alterations in an experimental pressure overload model. Int. J. Mol. Sci. 2017, 18, 1664. [CrossRef] [PubMed]

106. Zhang, X.; Qiao, Y.; Wu, Q.; Chen, Y.; Zou, S.; Liu, X.; Zhu, G.; Zhao, Y.; Chen, Y.; Yu, Y.; et al. The essential role of YAP O-GlcNAcylation in high-glucose-stimulated liver tumorigenesis. Nat. Commun. 2017, 8, 1-15. [CrossRef] [PubMed]

107. Wang, L.; Chennupati, R.; Jin, Y.J.; Li, R.; Wang, S.P.; Günther, S.; Offermanns, S. YAP/TAZ Are Required to Suppress Osteogenic Differentiation of Vascular Smooth Muscle Cells. IScience 2020, 23, 101860. [CrossRef] [PubMed]

108. Uemura, M.; Nagasawa, A.; Terai, K. Yap/Taz transcriptional activity in endothelial cells promotes intramembranous ossification via the BMP pathway. Sci. Rep. 2016, 6, 1-12. [CrossRef] [PubMed]

109. Xu, T.H.; Du, Y.; Sheng, Z.; Li, Y.; Qiu, X.; Tian, B.; Yao, L. OGT-Mediated KEAP1 Glycosylation Accelerates NRF2 Degradation Leading to High Phosphate-Induced Vascular Calcification in Chronic Kidney Disease. Front. Physiol. 2020, 11, 1092. [CrossRef]

110. Dai, X.Y.; Zhao, M.M.; Cai, Y.; Guan, Q.C.; Zhao, Y.; Guan, Y.; Kong, W.; Zhu, W.G.; Xu, M.J.; Wang, X. Phosphate-induced autophagy counteracts vascular calcification by reducing matrix vesicle release. Kidney Int. 2013, 83, 1042-1051. [CrossRef] 
111. Liu, Y.; Li, J.; Han, Y.; Chen, Y.; Liu, L.; Lang, J.; Yang, C.; Luo, H.; Ning, J. Advanced glycation end-products suppress autophagy by AMPK/mTOR signaling pathway to promote vascular calcification. Mol. Cell Biochem. 2020, 471, 91-100. [CrossRef]

112. Thompson, B.; Towler, D.A. Arterial calcification and bone physiology: Role of the bone-vascular axis. Nat. Rev. Endocrinol. 2012, 8, 529-543. [CrossRef] [PubMed]

113. Liu, S.; Quarles, L.D. How fibroblast growth factor 23 works. J. Am. Soc. Nephrol. 2007, 18, 1637-1647. [CrossRef]

114. Scialla, J.J.; Lau, W.L.; Reilly, M.P.; Isakova, T.; Yang, H.Y.; Crouthamel, M.H.; Chavkin, N.W.; Rahman, M.; Wahl, P.; Amaral, A.P.; et al. Fibroblast growth factor 23 is not associated with and does not induce arterial calcification. Kidney Int. 2013, 83, 1159-1168. [CrossRef]

115. Sprecher, E. Familial tumoral calcinosis: From characterization of a rare phenotype to the pathogenesis of ectopic calcification. $J$. Investig. Dermatol. 2010, 130, 652-660. [CrossRef]

116. Duncan, E.L.; Danoy, P.; Kemp, J.P.; Leo, P.J.; McCloskey, E.; Nicholson, G.C.; Eastell, R.; Prince, R.L.; Eisman, J.A.; Jones, G.; et al. Genome-wide association study using extreme truncate selection identifies novel genes affecting bone mineral density and fracture risk. PLoS Genet. 2011, 7, 1-10. [CrossRef] [PubMed]

117. Desjardins, L.; Liabeuf, S.; Renard, C.; Lenglet, A.; Lemke, H.D.; Choukroun, G.; Drueke, T.B.; Massy, Z.A. FGF23 is independently associated with vascular calcification but not bone mineral density in patients at various CKD stages. Osteoporos. Int. 2012, 23, 2017-2025. [CrossRef]

118. Freedman, B.I.; Divers, J.; Russell, G.B.; Palmer, N.D.; Bowden, D.W.; Carr, J.J.; Wagenknecht, L.E.; Hightower, R.C.; Xu, J.; Smith, S.C.; et al. Plasma FGF23 and Calcified Atherosclerotic Plaque in African Americans with Type 2 Diabetes Mellitus. Am. J. Nephrol. 2015, 42, 391-401. [CrossRef]

119. Chen, Y.X.; Huang, C.; Duan, Z.B.; Xu, C.Y.; Chen, Y. Klotho/FGF23 axis mediates high phosphate-induced vascular calcification in vascular smooth muscle cells via Wnt7b/ $\beta$-catenin pathway. Kaohsiung J. Med. Sci. 2019, 35, 393-400. [CrossRef] [PubMed]

120. Lindberg, K.; Olauson, H.; Amin, R.; Ponnusamy, A.; Goetz, R.; Taylor, R.F.; Mohammadi, M.; Canfield, A.; Kublickiene, K.; Larsson, T.E. Arterial Klotho Expression and FGF23 Effects on Vascular Calcification and Function. PLoS ONE 2013, 8, e60658. [CrossRef]

121. Kim, S.H.; Kim, Y.H.; Song, M.; An, S.H.; Byun, H.Y.; Heo, K.; Lim, S.; Oh, Y.S.; Ryu, S.H.; Suh, P.G. O-GlcNAc modification modulates the expression of osteocalcin via OSE2 and Runx2. Biochem. Biophys. Res. Commun. 2007, 362, 325-329. [CrossRef]

122. Jonason, J.H.; Xiao, G.; Zhang, M.; Xing, L.; Chen, D. Post-translational regulation of Runx2 in bone and cartilage. J. Dent. Res. 2009, 88, 693-703. [CrossRef] [PubMed]

123. Nagel, A.K.; Ball, L.E. O-GlcNAc modification of the runt-related transcription factor 2 (Runx2) links osteogenesis and nutrient metabolism in bone marrow mesenchymal stem cells. Mol. Cell Proteom. 2014, 13, 3381-3395. [CrossRef] [PubMed]

124. Wight, T.N. A Role for Proteoglycan in Vascular Disease. Matrix Biol. 2018, 71-72, 396-420. [CrossRef]

125. Wight, T.N.; Merrilees, M.J. Proteoglycans in atherosclerosis and restenosis: Key roles for versican. Circ. Res. 2004, 94, 1158-1167. [CrossRef]

126. Little, P.J.; Tannock, L.; Olin, K.L.; Chait, A.; Wight, T.N. Proteoglycans synthesized by arterial smooth muscle cells in the presence of transforming growth factor- $\beta 1$ exhibit increased binding to LDLs. Arterioscler. Thromb. Vasc. Biol. 2002, 22, 55-60. [CrossRef]

127. Nagy, N.; Kuipers, H.F.; Frymoyer, A.R.; Ishak, H.D.; Bollyky, J.B.; Wight, T.N.; Bollyky, P.L. 4-Methylumbelliferone treatment and hyaluronan inhibition as a therapeutic strategy in inflammation, autoimmunity, and cancer. Front. Immunol. 2015, 6, 1-11. [CrossRef] [PubMed]

128. Liu, D.; Cui, W.; Liu, B.; Hu, H.; Liu, J.; Xie, R.; Yang, X.; Gu, G.; Zhang, J.; Zheng, H. Atorvastatin protects vascular smooth muscle cells from TGF- $\beta 1$-stimulated calcification by inducing autophagy via suppression of the $\beta$-catenin pathway. Cell Physiol. Biochem. 2014, 33, 129-141. [CrossRef] [PubMed]

129. Nishimura, R.; Wakabayashi, M.; Hata, K.; Matsubara, T.; Honma, S.; Wakisaka, S.; Kiyonari, H.; Shioi, G.; Yamaguchi, A.; Tsumaki, N.; et al. Osterix regulates calcification and degradation of chondrogenic matrices through matrix metalloproteinase 13 (MMP13) expression in association with transcription factor Runx2 during endochondral ossification. J. Biol. Chem. 2012, 287, 33179-33190. [CrossRef]

130. Kiyono, K.; Suzuki, H.I.; Matsuyama, H.; Morishita, Y.; Komuro, A.; Kano, M.R.; Sugimoto, K.; Miyazono, K. Autophagy is activated by TGF- $\beta$ and potentiates TGF- $\beta$-mediated growth inhibition in human hepatocellular carcinoma cells. Cancer Res. 2009, 69, 8844-8852. [CrossRef]

131. Su, Z.; Zong, P.; Chen, J.; Yang, S.; Shen, Y.; Lu, Y.; Yang, C.; Kong, X.; Sheng, Y.; Sun, W. Celastrol attenuates arterial and valvular calcification via inhibiting BMP2/Smad1/5 signalling. J. Cell. Mol. Med. 2020, 24, 12476-12490. [CrossRef] [PubMed] 